\title{
Detection of Bermuda Grass White Leaf Disease in Italy and Characterization of the Associated Phytoplasma by RFLP Analysis
}

\author{
C. Marcone and A. Ragozzino, Istituto di Patologia Vegetale, Università di Napoli 'Federico II', I-80055 Portici \\ (Napoli), Italy; and E. Seemüller, Biologische Bundesanstalt für Land- und Forstwirtschaft, Institut für Pflanzen- \\ schutz im Obstbau, D-69221 Dossenheim, Germany
}

\begin{abstract}
Marcone, C., Ragozzino, A., and Seemüller, E. 1997. Detection of Bermuda grass white leaf disease in Italy and characterization of the associated phytoplasma by RFLP analysis. Plant Dis. $81: 862-866$.

Bermuda grass showing symptoms of a white leaf disease has been observed in fruit orchards, vegetable fields, and uncultivated areas in the Latium and Campania regions of central and southern Italy. Using polymerase chain reaction (PCR) amplification with phytoplasma-specific primers, all symptomatic plants tested positively; whereas no amplification product was obtained from nonsymptomatic plants. Restriction fragment length polymorphism (RFLP) analysis of the PCR-amplified ribosomal DNA revealed a uniform pattern that was similar to that of the Bermuda grass white leaf phytoplasma collected in Thailand, which is known to be a member of the sugarcane white leaf phytoplasma group. By RFLP analysis, the phytoplasma infecting Bermuda grass could be distinguished from other group members, including the phytoplasmas associated with sugarcane white leaf and Brachiaria white leaf. This is the first report on the presence of the Bermuda grass white leaf phytoplasma in Europe.
\end{abstract}

Bermuda grass, Cynodon dactylon (L.) Pers., is a perennial plant of the family Poaceae that is native to the Mediterranean region but is now widely distributed over many warm countries of the world. This species is affected by a yellows disease named Bermuda grass white leaf (BGWL) that is associated with a phytoplasma infection (5). The disease is characterized by extensive chlorosis, proliferation of axillary shoots, bushy growing habit, small leaves, shortened stolons and rhizomes, stunting, and death of the plants. Bermuda grass is also stunted from infection by the bacterium Clavibacter xyli $(8,9)$. Double infections by phytoplasmas and bacteria appear to be synergistic in their debilitating effects on the plants (9). Although C. xyli subsp. cynodontis has been found in Bermuda grass showing white leaf symptoms, this bacterium obviously does not incite these symptoms but causes stunting only $(7,9)$. From Bermuda grass showing witches'-broom symptoms, spiroplasmas also were isolated but do not appear to be the causal agents $(4,19)$.

BGWL occurs in Taiwan (5), Thailand (14), and the Sudan (6). A similar, if not the same, disease, called yellow leaf, was observed in Israel and India $(2,20)$. Re-

Corresponding author: E. Seemüller E-mail: ba69ed@genius.embnet.dkfz-heidelberg.de

Accepted for publication 17 April 1997.

Publication no. D-1997-0609-02R

(C) 1997 The American Phytopathological Society striction fragment length polymorphism (RFLP) analysis of ribosomal DNA (rDNA) that was amplified by polymerase chain reaction (PCR) showed that the BGWL agent is closely related to the sugarcane white leaf (SCWL) phytoplasma $(17,22)$. Thus, it is a member of the phylogenetic SCWL group established by Seemüller et al. (24).

BGWL or other white leaf diseases of gramineous plants were not known to occur in Europe. However, we observed in the last few years in fruit orchards, vegetable fields, and uncultivated areas of the Latium and Campania regions of central and southern Italy a yellows disease of Bermuda grass that was readily distinguishable from herbicide damage. Affected plants occurred singly or in patches and showed the typical symptoms of BGWL (Fig. 1). Sometimes light green to yellow streaks on the leaves also were present. In this paper, we report on the identification of phytoplasmas in the diseased Bermuda grass by amplification of phytoplasmal rDNA through PCR and the characterization and differentiation of the presumable causal agent by RFLP analysis.

\section{MATERIALS AND METHODS}

Plant samples and phytoplasma reference strains. In the summer of 1996, 10 diseased plants of Bermuda grass showing typical white leaf symptoms and two nonsymptomatic plants of the same species were sampled in each the Campania region (near Caserta) and the Latium region (near Latina). Two samples from Bermuda grass plants affected by BGWL and three sam- ples from each SCWL-affected sugarcane and Brachiaria white leaf (BRAWL)-affected Brachiaria distachya, all collected in Thailand a few years ago and stored as lyophilized tissue, were included in this study.

For comparisons, phytoplasma reference strains, maintained in periwinkle $(\mathrm{Ca}$ tharanthus roseus), included AAY (American aster yellows from Florida), STOL (stolbur of pepper from Serbia), FBP (faba bean phyllody from the Sudan), SUNHP (sunnhemp witches'-broom from Thailand), GVX (Green Valley strain of western $\mathrm{X}$ disease from California), BVK (sugarcane white leaf-related phytoplasma from the leafhopper Psammotettix cephalotes collected in Germany), VAC (Vaccinium witches'-broom from Germany), ULW (elm yellows from France), and AT (apple proliferation from Germany). These strains represent all primary phylogenetic groups established by Seemüller et al. (24).

Microscopic examination. The Bermuda grass samples were examined for the presence of phytoplasmas and walled bacteria by fluorescence microscopy with DAPI (4'-6-diamidino-2-phenylindole) staining and by electron microscopy as described previously $(15,16)$.

DNA isolation. Fresh shoots with leaves from diseased and from nonsymptomatic Bermuda grass were examined. Young shoots with leaves were taken from healthy and infected periwinkles. DNA was extracted from approximately $1.0 \mathrm{~g}$ of tissue, employing a phytoplasma enrichment procedure as described previously (1). Lyophilized tissue was ground to a fine powder in a mill and then extracted as described by Doyle and Doyle (10).

Primers, PCR amplification, and RFLP analysis. The universal phytoplasma primer pair P1/P7 (23), derived from highly conserved ribosomal sequences, was chosen for all assays. These oligonucleotides prime at the $5^{\prime}$ end of the $16 \mathrm{~S}$ rRNA gene and in the $5^{\prime}$ region of the 23S rRNA gene, respectively, and amplify a DNA fragment of approximately 1,800 bp in length. PCR amplification and analysis of the PCR products were as described (16).

\section{RESULTS AND DISCUSSION}

Phytoplasma detection. By both fluorescence and electron microscopy, phytoplasmas were detected in relatively low 
numbers in sieve tubes of symptomatic but not nonsymptomatic Bermuda grass. However, no walled bacteria could be observed in diseased plants, either in the phloem or in the xylem (data not shown). Because in other work both kinds of bacteria were detectable with the two microscopic methods (6), it is unlikely that $C$. xyli subsp. cynodontis contributed to the symptoms.

Phytoplasmas also were detected by PCR amplification. Target DNA was amplified in assays of all 20 samples of diseased Bermuda grass collected in central and southern Italy but not in assays of samples from nonsymptomatic plants collected in the same areas. Amplification product also was obtained from two check samples of BGLW-affected Bermuda grass from Thailand. Similarly, amplification products were obtained from check samples of SCWL-affected sugarcane and BRAWL-affected $B$. distachya. Also, a DNA fragment of the expected size was amplified from all phytoplasma reference strains that were maintained in periwinkle, but not from healthy periwinkles (data not shown).

Identification, characterization, and differentiation of the BGWL phytoplasma. Following separate digestions of the PCR products with restriction endonucleases AluI, RsaI, Sau3AI, MseI, HhaI, TaqI, HinfI, HpaII, HaeIII, and KpnI, all phytoplasma-positive samples from Bermuda grass collected in both Italy and Thailand showed the same restriction profiles with each of these enzymes (Figs. 2 and 3). This result reveals that the white leaf disease of Bermuda grass observed in Italy is caused by a homogenous phytoplasma that is similar or identical to the BGWL agent in Thailand.

RFLP analysis of PCR-amplified rDNA has shown that the BGWL agent is closely related to the SCWL phytoplasma $(17,22)$. For this reason, the BGLW pathogen was assigned to the SCWL phytoplasma group, a distinct cluster within the phytoplasmas (24). SCWL group also includes the phytoplasma associated with rice yellow dwarf (RYD) (18), leafhopper-borne strain BVK (24), and the BRAWL agent (17). Because in previous work only a few restriction enzymes were used in RFLP analysis, the various group members mostly could not be differentiated. Thus, in order to determine whether the BGWL strains from both Italy and Thailand can be distinguished from the BRAWL and SCWL phytoplasmas and strain BVK, we employed for this differentiation all enzymes which we used to compare Italian and Thai strains of the BGWL phytoplasma.

In this comparison, the phytoplasma infecting $B$. distachya showed with all but one endonuclease the same restriction profiles as the BGWL phytoplasma (Figs. 2 and 3). This one exception, which was not observed by Nakashima et al. (17), was the digestion with HinfI. In digestions of
rDNA from the BRAWL phytoplasma, additional bands were obtained with all enzymes used. These bands may be due either to mixed infections or to sequence heterogeneity of the two phytoplasmal rRNA operons, as observed in other phytoplasma-infected plants $(3,11,13)$. Differences between the BGWL and BRAWL phytoplasmas were also found in serological tests, in which antibodies to the BGWL agent did not react with BRAWL phytoplasma antigens (21).

The BGWL phytoplasma could clearly be distinguished from the SCWL agent. This pathogen differed in the AluI, Sau3AI, MseI, TaqI, HinfI, and HaeIII profiles from the BGWL phytoplasma (Fig. 2 and 3). The differences in the TaqI profiles have also been observed by Nakashima et al. (17), who examined a considerably shorter
rDNA fragment and fewer restriction endonucleases. In a serological comparison, no cross-reaction was observed in reciprocal tests between the BGWL and SCWL phytoplasmas and their antisera, thus confirming the results of the RFLP analysis and indicating separate identities of these organisms (21).

The BGWL phytoplasma differed from strain BVK in the AluI, Sau3A, MseI, TaqI, HinfI, and HaeIII profiles (Figs. 2 and 3). The differences in the $A l u \mathrm{I}$ sites are in contrast to the findings of Schneider et al. (22) but can be explained by the longer fragment we examined that included the $16 \mathrm{~S} / 23 \mathrm{~S}$ rDNA spacer region, in which the two differing restriction sites are located. As revealed by analyzing the sequence of the 16S rRNA gene of the RYD phytoplasma (accession no. D12581), this
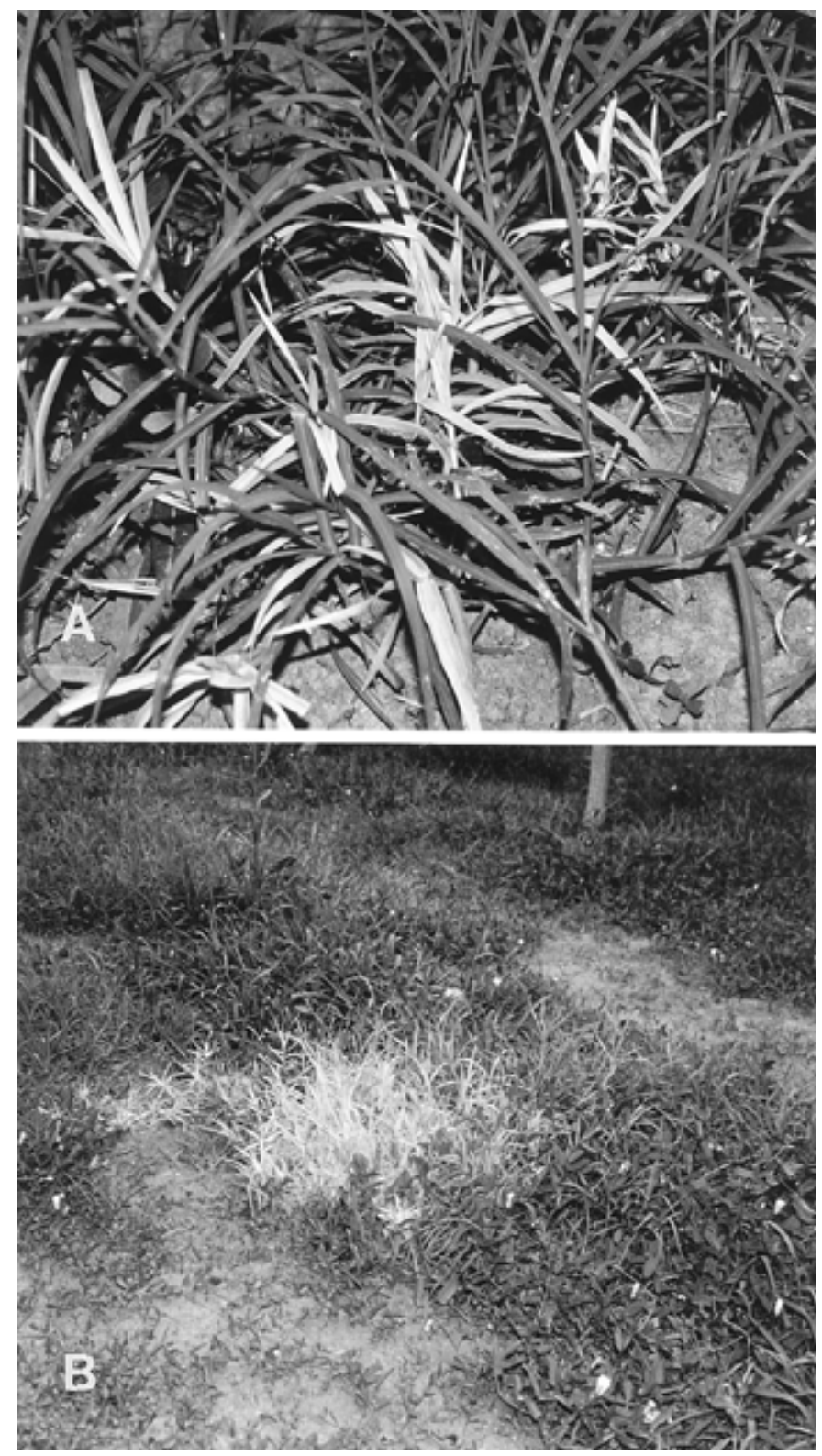

Fig. 1. Diseased plants of Cynodon dactylon affected by the Bermuda grass white leaf disease showing symptoms of general chlorosis. The affected plants, which appeared (A) singly or (B) in patches, are easily recognizable within the healthy, uniform green vegetation. 

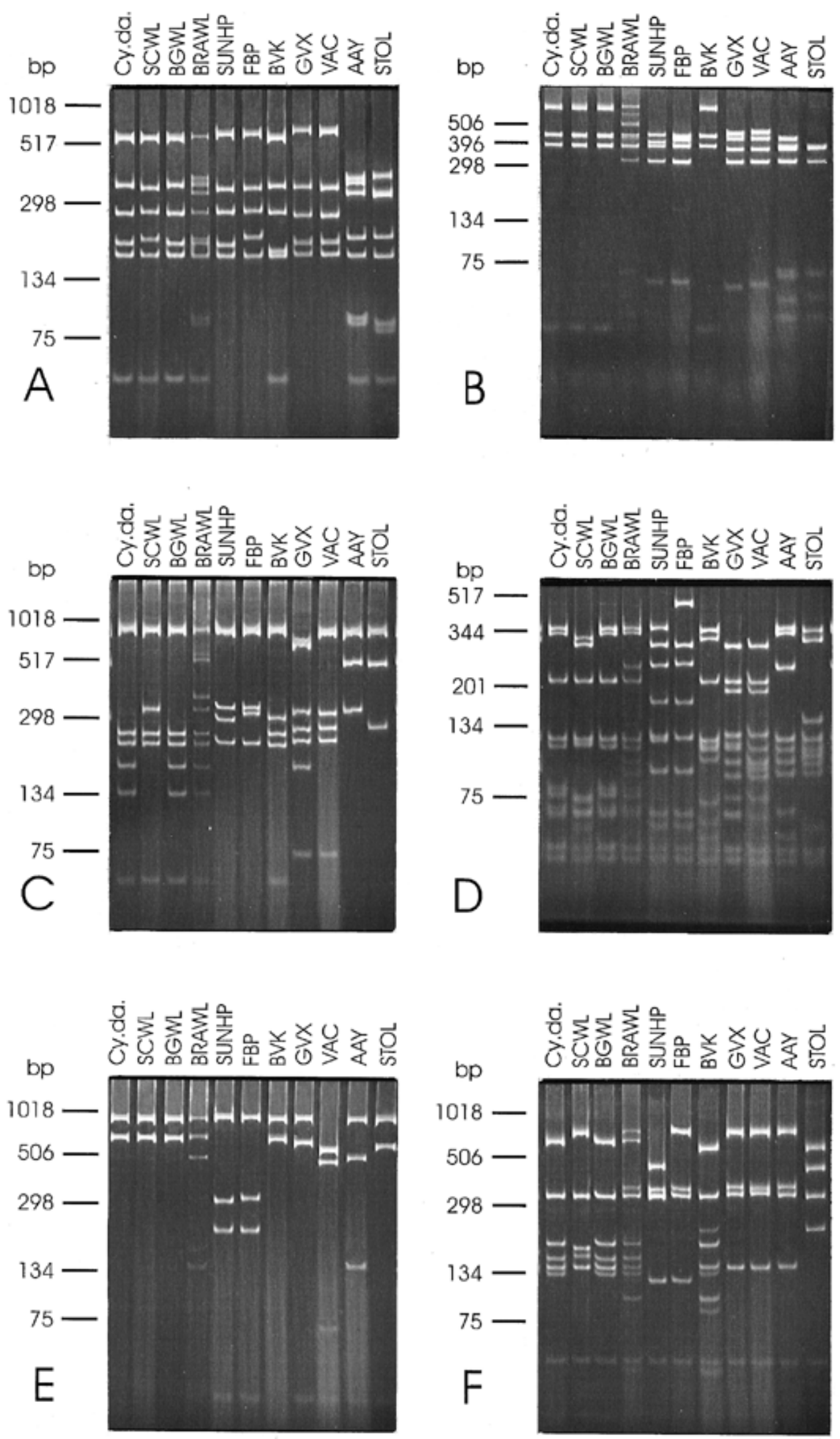

Fig. 2. (A) AluI, (B) RsaI, (C) Sau3AI, (D) MseI, (E) HhaI, and (F) TaqI restriction profiles of ribosomal phytoplasmal DNA amplified by polymerase chain reaction using universal primer pair P1/P7. Cy. da., diseased Bermuda grass from Italy; SCWL, sugarcane white leaf from Thailand; BGWL, Bermuda grass white leaf from Thailand; BRAWL, Brachiaria white leaf from Thailand; SUNHP, sunnhemp witches'-broom; FBP, faba bean phyllody; BVK, sugarcane white leaf-related strain from leafhopper; GVX, western X-disease; VAC, Vaccinium witches'-broom; AAY, American aster yellows; STOL, stolbur. 

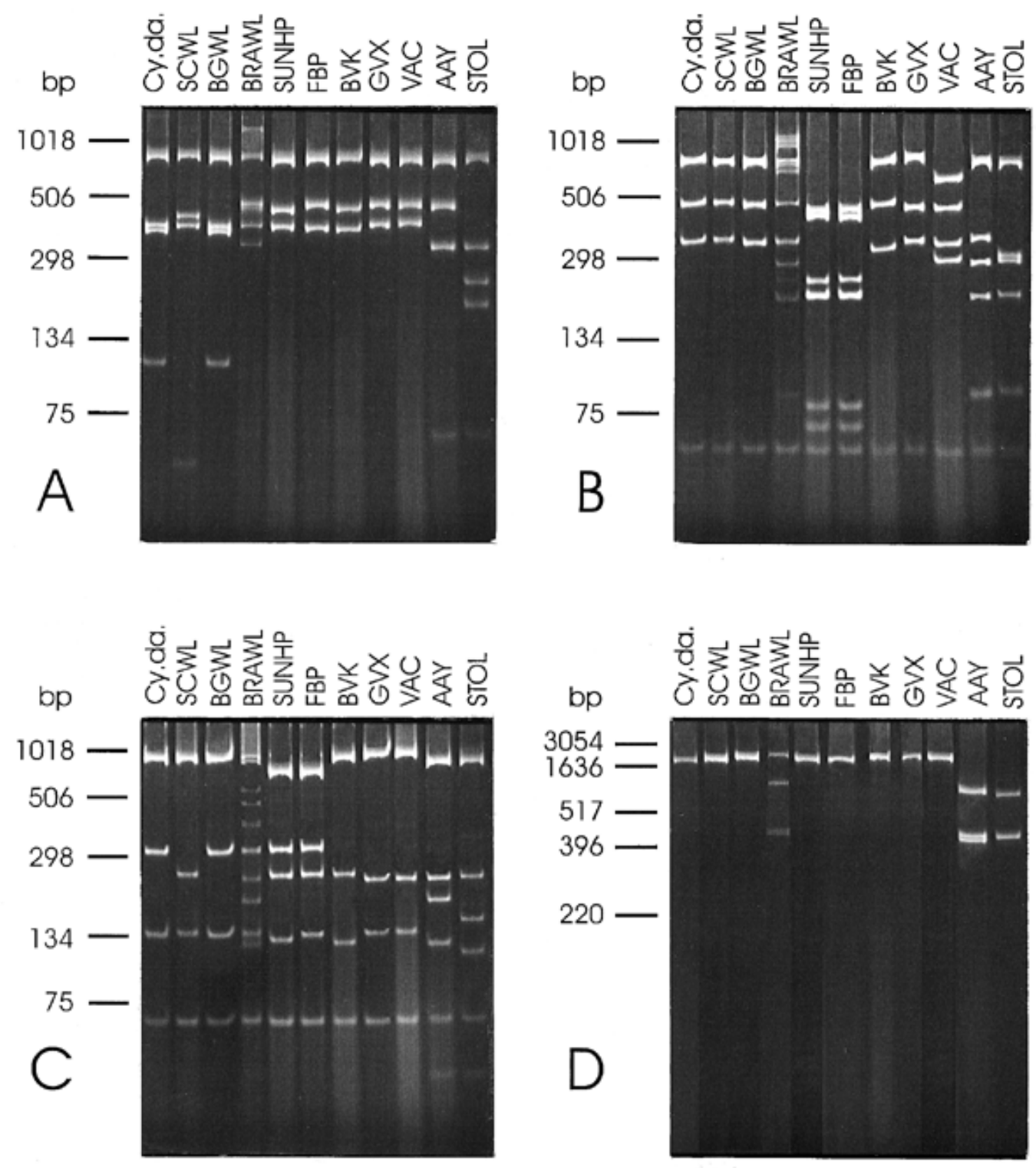

Fig. 3. (A) HinfI, (B) HpaII, (C) HaeIII, and (D) KpnI restriction profiles of ribosomal phytoplasmal DNA amplified by polymerase chain reaction assay using universal primer pair P1/P7. Cy. da., diseased Bermuda grass from Italy; SCWL, sugarcane white leaf from Thailand; BGWL, Bermuda grass white leaf from Thailand; BRAWL, Brachiaria white leaf from Thailand; SUNHP, sunnhemp witches'-broom; FBP, faba bean phyllody; BVK, sugarcane white leaf-related strain from leafhopper; GVX, western X-disease; VAC, Vaccinium witches'-broom; AAY, American aster yellows; STOL, stolbur.

pathogen also differs from the BGWL agent by the presence of an additional HaeIII site in the 16S rDNA in the former organism.

RFLP analysis of PCR-amplified rDNA is the preferred method to identify and differentiate phytoplasmas within primary phylogenetic groups that were established by $16 \mathrm{~S}$ rDNA sequence analysis. This straightforward method was introduced into phytoplasmology by Lee et al. (12) and Schneider et al. (22). It also proved highly suitable in our work, in which the BGWL agent could clearly be distinguished from other phytoplasmas from the SCWL group.

\section{ACKNOWLEDGMENTS}

We thank M. F. Clark, R. Marwitz, and W. A. Sinclair for supplying phytoplasma sources. This work was performed while the first author was a visiting postdoctoral scientist at the Dossenheim Institute. Work supported by funding from MIRAAF (progetto del piano nazionale biotecnologie vegetali).

\section{LITERATURE CITED}

1. Ahrens, U., and Seemüller, E. 1992. Detection of DNA of plant pathogenic mycoplasmalike organisms by a polymerase chain reaction that amplifies a sequence of the 16S rRNA gene. Phytopathology 82:828-832.

2. Bar-Joseph, M., Zelcer, A., and Loebenstein, G. 1975. Association of mycoplasmalike organisms with Bermudagrass yellow leaf. Phytopathology 65:640-641.
3. Berges, R., Cousin, M. T., Roux, J., and Seemüller, E. 1977. Detection of phytoplasma infections in declining Populus nigra 'Italica' trees and molecular differentiation of the aster yellows phytoplasmas identified in various Populus species. Eur. J. For. Pathol. 27:33-43.

4. Chen, T. A., Su, H. J., Raju, B. C., and Huang, W. C. 1977. A new spiroplasma isolated from Bermuda grass Cynodon dactylon L. Per. (Abstr.) Proc. Am. Phytopathol. Soc. 4:171.

5. Chen, T. C., Lee, C. S., and Chen, M. J. 1972. Mycoplasmalike organisms in Cynodon dactylon and Brachiaria distachya affected by white leaf disease. Rep. Taiwan Sugar Exp. Stn. 56:49-55.

6. Dafalla, G. A., and Cousin, M. T. 1988. Fluorescence and electron microscopy of Cynodon dactylon affected with a white leaf disease in Sudan. J. Phytopathol. 122:25-34. 
7. Davis, M. J., Gillaspie, A. G., Jr., Harris, R. W., and Lawson, R. H. 1980. Ratoon stunting disease of sugarcane: Isolation of the causal bacterium. Science 240:1365-1367.

8. Davis, M. J., Gillaspie, A. G., Jr., Vidavfer, A. K., and Harris, R. W. 1984. Clavibacter: A new genus containing some phytopathogenic coryneform bacteria, including Clavibacter xyli subsp. xyli sp. nov. subsp. nov. and Clavibacter xyli subsp. cynodontis subsp. nov., pathogens that cause ratoon stunting disease of sugarcane and Bermudagrass stunting disease. Int. J. Syst. Bacteriol. 34:107-117.

9. Davis, M. J., Lawson, R. H., Gillaspie, A. G., Jr., and Harris, R. W. 1983. Properties and relationships of two xylem-limited bacteria and a mycoplasmalike organism infecting Bermuda grass. Phytopathology 73:341-346

10. Doyle, J. J., and Doyle, J. L. 1990. Isolation of plant DNA from fresh tissue. Focus (Life Technologies Inc.) 12:13-15.

11. Lee, I.-M., Bertaccini, A., Vibio, M., and Gundersen, D. E. 1995. Detection of multiple phytoplasmas in perennial fruit trees with decline symptoms in Italy. Phytopathology 85:728-735.

12. Lee, I.-M., Hammond, R. W., Davis, R. E., and Gundersen, D. E. 1993. Universal amplification and analysis of pathogen $16 \mathrm{~S}$ rDNA for classification and identification of mycoplasmalike organisms. Phytopathology 83:834-
842.

13. Liefting, L. W., Andersen, M. T., Beever, R. E., Gardner, R. C., and Forster, R. L. S., 1996. Sequence heterogeneity in the two $16 \mathrm{~S}$ rRNA genes of Phormium yellow leaf phytoplasma. Appl. Environ. Microbiol. 62:3133-3139.

14. Maramorosch, K., Kimura, M., and Chareonridhi, S. 1975. Mycoplasmalike organisms associated white leaf disease in Thailand. FAO Plant Prot. Bull. 23:137-139.

15. Marcone, C., Firrao, G., Ragozzino, A., and Locci, R. 1994. Detection of MLOs in declining alder trees in Southern Italy and their characterization by RFLP analysis. Eur. J. For. Pathol. 24:217-228.

16. Marcone, C., Ragozzino, A., Schneider, B., Lauer, U., Smart, C. D., and Seemüller, E. 1996. Genetic characterization and classification of two phytoplasmas associated with Spartium witches'-broom disease. Plant Dis. 80:365-371.

17. Nakashima, K., Hayashi, T., Chaleeprom, W., Wongkaew, P., and Sirithorn, P. 1996. Complex phytoplasma flora in Northeast Thailand as revealed by $16 \mathrm{~S}$ rDNA analysis. Ann. Phytopathol. Soc. Jpn. 62:57-60.

18. Namba, S., Oyaizu, H., Kato, S., Iwanami, S., and Tsuchizaki, T. 1993. Phylogenetic diversity of phytopathogenic mycoplasmalike organisms. Int. J. Syst. Bacteriol. 43:461-467.

19. Raju, B. C., and Chen, T. A. 1980. Growth, morphology and ultrastructural studies of a spiroplasma associated with Bermudagrass showing witches'-broom symptoms. Z. Pflanzenkrankh. Pflanzenschutz 87:37-45.

20. Rishi, N. 1978. Association of mycoplasma like bodies (MLB) with yellow disease of Cynodon dactylon and its relationship with grassy shoot disease of sugarcane in India. (Abstr.) Int. Congr. Plant Pathol., 3rd. p. 80.

21. Sarindu, N., and Clark, M. F. 1993. Antibody production and identity of MLOs associated with sugar-cane whiteleaf disease and Bermuda-grass whiteleaf disease from Thailand Plant Pathol. 42:396-402.

22. Schneider, B., Ahrens, U., Kirkpatrick, B. C., and Seemüller, E. 1993. Classification of plant-pathogenic mycoplasma-like organisms using restriction-site analysis of PCR-amplified 16S rDNA. J. Gen. Microbiol. 139:519 527.

23. Schneider, B., Seemüller, E., Smart, C. D., and Kirkpatrick, B. C. 1995. Phylogenetic classification of plant pathogenic mycoplasma-like organisms or phytoplasmas. Pages 369-380 in: Molecular and Diagnostic Procedures in Mycoplasmology, Vol. I. S. Razin and J. G. Tully, eds. Academic Press, San Diego.

24. Seemüller, E., Schneider, B., Mäurer, R., Ahrens, U., Daire, X., Kison, H., Lorenz, K.H., Firrao, G., Avinent, L., Sears, B. B., and Stackebrandt, E. 1994. Phylogenetic classification of phytopathogenic mollicutes by sequence analysis of $16 \mathrm{~S}$ ribosomal DNA. Int J. Syst. Bacteriol. 44:440-446. 